\title{
Chemical composition, antimicrobial and antioxidant potential of the essential oil of Guarea kunthiana A. Juss
}

\author{
J. A. Pandini ${ }^{a}$, F. G. S. Pinto ${ }^{a *}$, M. C. Scur ${ }^{a}$, C. B. Santana ${ }^{a}$, W. F. Costa ${ }^{b}$ and L. G. Temponi ${ }^{c}$
}

a'Laboratório de Biotecnologia, Programa de Conservação e Manejo de Recursos Naturais, Universidade Estadual do Oeste do Paraná - UNIOESTE, Rua Universitaria, 2069, Jardim Universitario, CEP 85819-110, Cascavel, PR, Brazil

bDepartamento de Química, Universidade Estadual de Maringá - UEM, Av. Colombo 5790, Jardim Iniversitario, CEP 87020-900, Maringá, PR, Brazil

'Laboratório de Botânica, Programa de Conservação e Manejo de Recursos Naturais, Universidade Estadual do Oeste do Paraná - UNIOESTE, Rua Universitaria, 2069, CEP 85819-110, Cascavel, PR, Brazil

*e-mail: fabiana.pinto@unioeste.br

Received: March 29, 2016 - Accepted: September 14, 2016 - Distributed: February 28, 2018

\begin{abstract}
The essential oils are extracted from plant compounds and can present activities antimicrobial and antioxidant properties. The goals of the present study were: (a) to determine the chemical composition of the essential oil of Guarea kunthiana A. Juss using the method of gas chromatography coupled to mass spectrometry (GC-MS); (b) to evaluate the antimicrobial potential of this oil using the broth microdilution method against different microorganisms: five Gram-negative bacteria, four Gram-positive bacteria and a yeast and (c) to determine the antioxidant activity of the oil using the DPPH (2,2-diphenyl-1-picrylhydrazyl) free radical assay. The GC-MS analyses allowed identifying 13 constituents, representing $96.52 \%$ of the essencial oil composition. The main compounds identified were $\alpha$-zingiberene (34.48\%), $\beta$-sesquiphellandrene (22.90\%), and $\alpha$-curcumene (16.17\%). With respect to the antimicrobial activity, the essential oil was effective against all the microorganisms tested, except for the bacteria E. coli and K. pneumoniae, which were resistant to the action of the oil. From a general point of view, Gram-positive bacteria were more susceptible to the action of the essential oil than Gram-negative bacteria. The essential oil exhibited antioxidant potential.
\end{abstract}

Keywords: Guarea kunthiana, essential oil, chemical composition, antimicrobial activity, antioxidant.

\section{Composição química, potencial antimicrobiano e antioxidante do óleo essencial de Guarea kunthiana A. Juss}

\section{Resumo}

Os óleos essenciais são compostos extraídos de plantas e podem apresentar propriedades antimicrobianas e antioxidantes. O objetivo deste trabalho foi (a) determinar a composição química do óleo essencial de Guarea kunthiana A. Juss pelo método de cromatografia gasosa acoplada à espectrometria de massas (CG-EM); (b) avaliar o potencial antimicrobiano deste óleo pelo método de microdiluição em caldo frente a diferentes micro-organismos, sendo cinco bactérias Gram-negativas, quatro Gram-positivas uma levedura e (c) por fim, determinar a atividade antioxidante do óleo pelo método de captura do radical livre 2,2-difenil-1-picril hidrazil (DPPH). As análises de CG-EM resultaram na identificação de 13 constituintes, representando 96,52\% da composição do óleo essencial. Os principais compostos identificados foram $\alpha$-Zingibereno (34,48\%), $\beta$-Sesquifelandreno $(22,90 \%)$ e $\alpha$-Curcumeno $(16,17 \%)$. Em relação à atividade antimicrobiana, o óleo essencial foi efetivo frente a todos os micro-organismos testados exceto para as bactérias E. coli e K. pneumoniae, as quais se apresentaram resistentes à ação do óleo. Em geral, as bactérias Gram-positivas foram mais suscetíveis à ação do óleo essencial em relação às Gram-negativas. O óleo essencial apresentou potencial.

Palavras-chave: Guarea kunthiana, óleo essencial, composição química, atividade antimicrobiana, antioxidante.

\section{Introduction}

Brazil has the largest plant biodiversity in the world, with about $20 \%$ of the number of species on the planet. Essential oils with medicinal properties are among the main products of plant origin (Sartoratto et al., 2004) that have stood out in the industrial sector as ingredients in food, cosmetic and sanitizers formulations, as well as in alternative medicine and natural therapies (Ceyhan et al., 2012; Scherer and Godoy, 2009). In addition, essential oils may have antimicrobial and insecticidal properties. Studies relating to these properties are of extreme relevance, 
especially those addressing plants with unknown biological potential (Krifa et al., 2011).

Essential oils are chemically characterized as complex mixtures of low molecular weight compounds and, some of them, are highly volatile and capable of generating flavors and/or aromas (Trombetta et al., 2005). Scientific studies have shown the role of essential oils in biological interactions among plants and their potential therapeutic including anti-inflammatory, analgesic, anti-tumor, antifungal, and antibacterial activities (Siani et al., 2000; Silva et al., 2003; Sousa et al., 2004; Osei-Safo et al., 2010; Kaileh et al., 2007).

In addition to the abovementioned properties, many essential oils have been confirmed to possess antioxidant activity. They are extremely important for disease prevention, since they inhibit and delay the oxidation of biomolecules by preventing the initiation or propagation of chain oxidation reactions (Kaur and Kapoor, 2001; Bamoniri et al., 2010; Quariachi et al., 2011). Due to the harmful effects that synthetic antioxidants may cause, such as toxicity and carcinogenicity, the interest in the discovery of natural antioxidants has increased considerably (Losso et al., 2007).

The growing interest in natural bioactive compounds has led to conduct further studies addressing the replacement of synthetic chemical agents in the industrial sector, since natural products are less harmful to health (Gao et al., 2011), in addition to being biodegradable and usually exhibiting low toxicity in mammals (Figueiredo et al., 2008).

The family Meliaceae has pantropical distribution, including about 50 genera and 600 species. In Brazil, there are six genera and about 100 species (Lorenzi and Matos, 2008). The members of this family have a wide diversity of chemical compounds, including limonoids, triterpenes, steroids, diterpenes, sesquiterpenes and coumarins (Cortez et al., 2000; Lago et al., 2000, 2002; Soares et al., 2012; Scur et al., 2016). Limonoids are the most abundant compounds and, probably, the largest representatives of the class of terpenes with insecticidal activity (Luo et al., 1999). In addition to these properties, these compounds can also perform as antitumor, antifungal, bactericidal, antiviral (Champagne et al., 1992), antioxidant (Jayaprakasha and Patil, 2007), leishmanicidal (Lima, 2006), and antimalarial (Kaur et al., 2009) agents.

One of the species belonging to the family Meliaceae is Guarea kunthiana A. Juss, popularly known as jatuauba, figo-do-mato, peloteira, and jitó. It is a tree native to Brazil and has wide geographic distribution throughout the national territory (Lorenzi, 2009). Studies conducted on extracts from the roots of this plant have reported antiparasitic (Lima, 2006; Mesquita et al., 2005) and insecticidal (Coelho, 2006) activities. Phytochemical studies have indicated the occurrence of diterpenes and sesquiterpenes in ethanolic extract obtained from the leaves of G. kunthiana (Garcez et al., 2004) and a limonoid ecuadorin isolated from the dichloromethane extract of the leaves (Mootoo et al., 1992). However, the antimicrobial and antioxidant potential and the chemical composition of the essential oil of G. kunthiana have not been reported in the literature.
Thus, the goal of the present study was to determine the chemical composition of the essential oil of G. kunthiana and its antimicrobial potential against different microorganisms (five Gram-negative bacteria, four Gram-positive bacteria, and yeast Candida albicans), in addition to assessing its antioxidant activity.

\section{Material and Methods}

\subsection{Collection and identification of plant material}

The leaves of G. kunthiana were collected from September to December 2014 in a rural property of the western region of the State of Paraná, Brazil (Latitude 2431' S, Longitude $53^{\circ} 44^{\prime}$ W, altitude of $442 \mathrm{~m}$ ). Drying of the leaves was held in an oven at $35^{\circ} \mathrm{C}$ for subsequent milling in a knife mill until obtaining the crushed plant material with particle size less than $0.42 \mathrm{~mm}$. An exsiccate specimen was sent to the Herbarium of the State University of Oeste do Paraná (UNOP) for botanical identification, deposited under number 7843 Pandini, J. A.

\subsection{Obtaining essential oil}

Aerial parts of G. kunthiana (60 g) were submitted to extraction by hydrodistillation in $700 \mathrm{~mL}$ of distilled water for four hours using a Clevenger-type apparatus. The essential oil were colleted, dried over anhydrous sodium sulphate $(\sim 1 \mathrm{~g})$, and stored at $4{ }^{\circ} \mathrm{C}$ until analyzed. The essential oil yield was $0.35 \%(\mathrm{w} / \mathrm{w})$ dry weight.

\subsection{GC-MS analysis}

The analyses of the essential oil compounds was performed using a FOCUS GS gas chromatograph (Thermo Electron) coupled to a DSQ II mass spectrometer (Thermo Electron) and a detector with electron ionization impact at $70 \mathrm{eV}$ and quadrupole-type mass analyzer. Chromatographic separation was carried out using a DB-5 fused-silica capillary column $(30 \mathrm{~m} \times 0.25 \mathrm{~mm}$ inner diameter, film thickness $0.25 \mu \mathrm{m}$ ) and $5 \%$ phenyl $/ 95 \%$ dimethylpolysiloxane stationary phase.

The injector temperature was $250^{\circ} \mathrm{C}$ and the carrier gas flow was kept constant at $1 \mathrm{~mL} \cdot \mathrm{min}^{-1}$. The sample and the alkane standards C7-C28 were injected at a split-ratio of $1: 25$. The temperature program was: initial temperature of $50{ }^{\circ} \mathrm{C} / 2 \mathrm{~min}$; followed by an increase to $180{ }^{\circ} \mathrm{C} / 2^{\circ} \mathrm{C} \mathrm{min}{ }^{-1}$, and $290{ }^{\circ} \mathrm{C} / 5{ }^{\circ} \mathrm{C} \mathrm{min}{ }^{-1}$. The interface between the $\mathrm{GC}$ and the MS was kept at $270{ }^{\circ} \mathrm{C}$, and the temperature of the ionization source for the mass spectrometric analysis was $250{ }^{\circ} \mathrm{C}$. The identification of the compounds was accomplished by comparing their retention times with the retention times obtained from the literature (Adams, 2007) and through their Retention Indices.

\subsection{Antimicrobial activity}

\subsubsection{Microorganisms and test conditions}

The essential oil of the plant was tested against different microorganisms: five Gram-negative bacteria (Escherichia coli ATCC 25922; Salmonella enterica subsp. Enterica ATCC 14028; Pseudomonas aeruginosa ATCC 
27853; Proteus mirabilis ATCC 25933; and Klebsiella pneumoniae ATCC 13883); four Gram-positive bacteria (Staphylococcus aureus ATCC 25923; Enterococcus faecalis ATCC 19433; Staphylococcus epidermidis ATCC 12228; and Bacillus subtilis CCD-04); and yeast Candida albicans ATCC 10231 (American Type Culture Collection, USA).

For the test, the microorganisms were grown in brain heart infusion enrichment broth (BHI) and incubated at $36 \pm 0.1{ }^{\circ} \mathrm{C}$ for 24 hours. After this period, microbial strains were standardized in saline solution $(0.85 \%)$ until they reached the final concentration of $1 \times 10^{5} \mathrm{UFC}_{\mathrm{mL}} \mathrm{m}^{-1}$, with the exception of yeast $C$. albicans that was diluted at the final concentration of $1 \times 10^{6}$ UFC. $\mathrm{mL}^{-1}$ to serve as inoculum.

\subsubsection{Determination of minimal inhibitory concentration (MIC)}

Minimal inhibitory concentration (MIC) was determined as the lowest oil concentration able to inhibit microbial growth. The microdilution test was performed according to the standards proposed by the Clinical Laboratory Standards Institute - CLSI (2007).

The essential oil was diluted with methanol and MuellerHinton broth for testing with the bacteria, and methanol and RPMI 1640 broth for C. albicans at a proportion of $1: 10$ until reaching the concentration of $7000 \mu \mathrm{g} \cdot \mathrm{mL}^{-1}$. A total of $150 \mu \mathrm{l}$ of Mueller-Hinton broth for the bacteria and RPMI 1640 broth for C. albicans were distributed from the second column in 96-well microtiter plates. The first columns received $300 \mu 1$ of oil of $G$. kunthiana and, thereafter, dilutions of 7000-3.4 $\mu \mathrm{g} \cdot \mathrm{mL}^{-1}$ were performed. Finally, $10 \mu \mathrm{L}$ of inoculum were added to each well and the plates were incubated at $36 \pm 0.1{ }^{\circ} \mathrm{C}$ for $18-24$ hours. Subsequently, an aliquot of $10 \mu \mathrm{L} 10 \%$ triphenyltetrazolium chloride (TTC) was added and the plates were again incubated at $36 \pm 0.1^{\circ} \mathrm{C}$ for three hours. The presence of red color was considered a negative evidence of inhibitory effect of the essential oil.

\subsubsection{Determination of the minimal bactericidal} concentration $(\mathrm{MBC})$ and minimal fungicidal concentration (MFC)

An aliquot of $10 \mu \mathrm{L}$ was withdrew from the wells where there was non-visible bacterial growth before the addition of TTC and inoculated on the surface of the Mueller-Hinton broth. The plates were incubated at $36 \pm 0.1^{\circ} \mathrm{C}$ for 24 hours and, after this period, the MBC and MFC were defined as the lowest concentration of essential oil capable of causing the death of the inoculum (Santúrio et al., 2007).

Methanol was used as negative control, and gentamicin for bacteria and nystatin for C. albicans were used for positive control. Both of them were tested at concentrations of $100-0.78 \mu \mathrm{g} . \mathrm{mL}^{-1}$

\subsubsection{Antioxidant activity}

The antioxidant activity was determined using the method of reducing the free radical DPPH (2,2-diphenyl-1-picrylhydrazyl) based on the method proposed by Scherer and Godoy
(2009), Rufino et al. (2007), and Weber et al. (2014). Hundred microlitres of various concentrations of the samples $\left(11,71-6000 \mu \mathrm{g} \cdot \mathrm{mL}^{-1}\right)$ were added to $3.9 \mathrm{~mL}$ of $\mathrm{DPPH}$ methanolic solution $(0.2 \mathrm{mM})$ and slightly homogenized in a tube agitator. After agitation, the tubes were left to stand for 30 minutes in the dark. After the reaction time, the absorbance of samples was measured at $515 \mathrm{~nm}$. An aliquot of $0.1 \mathrm{~mL}$ of control solution (methyl alcohol, acetone, and water) was used for the negative control and the synthetic antioxidant butylhydroxytoluene (BHT) was used for the positive control under the same conditions of the negative control. Methyl alcohol was used as blank for the calibration of the spectrophotometer. The ability of free radical sequestration was expressed by the equation $\mathrm{I} \%:\left[\left(\mathrm{Abs}_{0}-\mathrm{Abs}_{1}\right) / \mathrm{Abs}_{0}\right] \times 100$, where $\mathrm{Abs}_{0}$ is the absorbance of the control and $\mathrm{Abs}_{1}$ is the absorbance of the sample. The $\mathrm{IC}_{50}$ (amount of antioxidant substance required to reduce by $50 \%$ the initial DPPH concentration) was calculated on the basis of the equation of the line obtained from the calibration curve. The tests were carried out in triplicate.

\subsubsection{Analysis of data}

The data obtained by calculations of DPPH radical sequestration capacity and the $\mathrm{IC}_{50}$ were assessed using T test, at 5\% significance, employing the Sisvar software (Ferreira, 2011).

\section{Results and Discussion}

The GC-MS analysis identified 13 compounds, representing $96.52 \%$ of the total composition of the essential oil. The major compounds were $\alpha$-zingiberene (34.48\%), $\beta$-sesquiphellandrene (22.90\%), and $\alpha$-curcumene (16.17\%) (Table 1).

The compounds identified were mostly sesquiterpenic hydrocarbons (84.37\%), followed by kaurane diterpenes (9.95\%), and oxygenated sesquiterpene spathulenol (2.20\%). The occurrence of sesquiterpenes has been well evidenced in the essential oils of different Guarea species, such as: G. convergens; G. humaitensis; G. scabra; and G. silvatica, which exhibited mainly the presence of sesquiterpenic and oxygenated hydrocarbons, and kaurane diterpenes. Lago et al. (2000) assessed the compounds present in the essential oil of G. guidonia and only reported the occurrence of sesquiterpenes. Studies on the species G. macrophylla reported the occurrence of oxygenated sesquiterpenes, hydrocarbons, diterpenes, and also fatty acids exhibiting variations in different times of the year. In the summer, the sesquiterpene guai-6-en-10 $\beta$-ol was the major compound. On the other hand, $\gamma$-cadinene was the major compound in spring (Lago et al., 2000, 2006).

The variation of the chemical compounds present in essential oils can be attributed to different factors: seasonality; circadian rhythm; age and development of the plant; temperature; water availability; ultraviolet radiation; nutrient content; altitude; atmospheric pollution; and attack by pathogens (Gobbo-Neto and Lopes, 2007). Changes in some of these factors significantly influence the yield and composition of essential oils (Dudareva et al., 2004), which 
reflects the differences found when comparing different studies and different species.

With respect to the antimicrobial potential, the essential oil of $G$. kunthiana exhibited activity against all the microorganisms tested, except for the bacteria E. coli and $K$. pneumoniae, which were resistant to the action of the oil. MIC values ranged from 13.6 to $3500 \mu \mathrm{g} \cdot \mathrm{mL}^{-1}$ and $\mathrm{MBC}$ values from 54.6 to $3500 \mu \mathrm{g} \cdot \mathrm{mL}^{-1}$ for Gram-positive bacteria, and MIC and MBC of $7000 \mu \mathrm{g} \cdot \mathrm{mL}^{-1}$ for Gram-negative bacteria. For C. albicans, the MIC and MBC values were 1750 and $3500 \mu \mathrm{g} \cdot \mathrm{mL}^{-1}$, respectively (Table 2).

Gram-positive bacteria were more susceptible to the action of the essential oil than Gram-negative bacteria. There are no reports in the literature on the antimicrobial potential of the essential oil of G. kunthiana and studies on antimicrobial testing with essential oils of plants from the family Meliaceae are scarce. Data similar to those found in the present study were reported by Sairam et al. (2000) who assessed the antibacterial and antifungal potential of the essential oil of Azadirachta indica (Meliaceae) and found greater antimicrobial activity of the essential oil against Gram-positive bacteria than against Gram-negative bacteria. Aromdee and Sriubolmas (2006) assessed the antimicrobial potential of the mentioned plant and observed moderate antimicrobial activity against $B$. subtilis and C. albicans. On the other hand, Parthasarathy and Thombare (2013) reported activity only for Staphylococcus auricularis using the essential oil of this species.

The mechanisms of action of essential oils in bacterial cells involve different targets. One of the most important

Table 1. Volatile components of the essential oil of Guarea kunthiana obtained by GC-MS analysis.

\begin{tabular}{cccc}
\hline RT (min) $^{\mathbf{a}}$ & Components $^{\mathbf{b}}$ & Area (\%) & RI $^{\mathbf{c}}$ \\
\hline 35.27 & $\alpha$-copaene & 0.67 & 1373 \\
36.36 & $\beta$-elemene & 5.19 & 1386 \\
37.85 & E-Caryophyllene & 0.48 & 1414 \\
39.05 & $\alpha$-bergamoten & 1.91 & 1434 \\
40.51 & $\beta$-farnesene & 0.44 & 1459 \\
41.59 & Germacrene D & 0.52 & 1477 \\
41.93 & $\alpha$-curcumene & 16.17 & 1482 \\
42.72 & $\alpha$-zingiberene & 34.48 & 1495 \\
44.18 & Calamenene & 1.27 & 1520 \\
44.33 & $\beta$-sesquiphellandrene & 22.90 & 1523 \\
47.18 & Spathulenol & 2.20 & 1573 \\
52.58 & Cadalene & 0.34 & 1671 \\
69.66 & Kaurene & 9.95 & 2033 \\
Total & & 96.52 & - \\
Oxygenated sesquiterpenes & & 84.37 & - \\
Diterpenes & & 2.20 & - \\
\hline
\end{tabular}

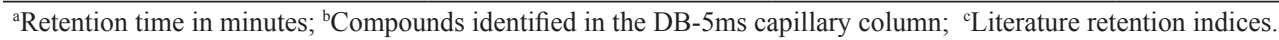

Table 2. Minimal inhibitory concentration, minimal bactericidal concentration, and minimal fungicidal concentration of the essential oil of Guarea kunthiana against microorganisms tested.

\begin{tabular}{|c|c|c|c|c|}
\hline & \multirow{2}{*}{ Microorganisms } & \multicolumn{3}{|c|}{ MIC/MBC (MFC) ${ }^{\mathrm{a}, *}$} \\
\hline & & Essential oil $^{\mathbf{b}}$ & Gentamicin $^{c}$ & Nystatin $^{\text {d }}$ \\
\hline \multirow{5}{*}{ Gram - } & E. coli & $\mathrm{Na}$ & $.78 / .78$ & $\mathrm{Nt}$ \\
\hline & P. aeruginosa & $7000 / 7000$ & $.78 / .78$ & $\mathrm{Nt}$ \\
\hline & S. enterica & $7000 / 7000$ & $.78 / .78$ & $\mathrm{Nt}$ \\
\hline & P. mirabilis & $7000 / 7000$ & $.78 / .78$ & $\mathrm{Nt}$ \\
\hline & K. pneumoniae & $\mathrm{Na}$ & $.78 / .78$ & $\mathrm{Nt}$ \\
\hline \multirow{4}{*}{ Gram + } & S. aureus & $13.6 / 54,6$ & $.78 / .78$ & $\mathrm{Nt}$ \\
\hline & E. faecalis & $437.5 / 875$ & $.78 / .78$ & $\mathrm{Nt}$ \\
\hline & S. epidermidis & $3500 / 3500$ & $.78 / .78$ & $\mathrm{Nt}$ \\
\hline & B. subtillis & $875 / 875$ & $.78 / .78$ & $\mathrm{Nt}$ \\
\hline Yeast & C. albicans & $1750 / 3500$ & $\mathrm{Nt}$ & $.78 / .78$ \\
\hline
\end{tabular}


features is the hydrophobicity of their components, which allows the partition of lipids of the bacterial cell membrane and mitochondria, disrupting the structures and leading to the leakage of the cell content (Burt, 2004). The greatest resistance of Gram-negative bacteria to the action of essential oils can occur due to the complexity of the double membrane of these microorganisms, which limits the diffusion of hydrophobic compounds through the lipopolysaccharide component (Burt, 2004; Holley and Patel, 2005).

The antimicrobial activity of essential oils depends on the chemical composition of the plant, which can vary according to the period of the year (Yesil-Celiktas et al., 2007). Among the compounds of the essential oil of $G$. kunthiana is $\alpha$-zingiberene. It has antimicrobial properties (Croteau et al., 2000) as reported for Zingiber officinale (ginger). This compound is the most prevalent in the essential oil of $Z$. officinale and has exhibited significant activity against some Gram-positive and Gram negative bacteria (Andrade et al., 2012). Antibacterial and antifungal properties are attributed to the other compounds, such as E-caryophyllene and germacrene-D (Costa et al., 2010; Veiga-Júnior and Pinto, 2002). On the other hand, spathulenol has antibacterial properties (Pacciaroni et al., 2000), which can explain the activity found.

Although some of these compounds feature low concentrations, they can have an effect on the overall efficiency of the antimicrobial activity of the essential oil through synergistic interaction with the other constituents (Burt, 2004; Vagionas et al., 2007; Giles et al., 2010). Although the major components many times account for more than $85 \%$ of the chemical characterization of essential oils, their proportions are not related to their great activity, which may be fundamental for the pharmacological action of the compounds with very small proportions (Galindo et al., 2010).

With respect to the results of antioxidant activity, it should be noted that $\mathrm{IC}_{50}$ values were inversely related to the percentage of DPPH scavenging capacity, i.e., the higher the scavenging rate, the lower the $\mathrm{IC}_{50}$ value. $\mathrm{T}$ test was used to assess the difference between the means, considering $p$-value less than $0.05(p<0.05)$ statistically significant (Table 3).

The analysis of the results of antioxidant activity of the essential oil demonstrated that there were significant differences between the essential oil and the commercial synthetic antioxidant (BHT). However, the difference in $\mathrm{IC}_{50}$ values between $\mathrm{BHT}$ values and the essential oil was small (9.27 for BHT and 17.54 for the essential oil). The same fact can be observed when comparing the percentage of DPPH radical scavenging capacity $(95.85 \%$ for the BHT and $91.52 \%$ for the essential oil), which demonstrates that the essential oil exhibited greater antioxidant activity at this concentration. At the other concentrations assessed, the essential oil exhibited low DPPH radical scavenging capacity (Table 3 ).

The free radical scavenging capacity of the essential oil of $G$. kunthiana can be attributed to the presence of some compounds, such as $\alpha$-zingiberene that plays an important role in defending some plants against oxidation (Rice-Evans et al., 1997). Other compoundssuch as E-caryophyllene-have recognized antioxidant activity, and they can have this capacity increased by the synergistic effect with other compounds (Shahidi et al, 1992; Morais et al., 2006).

The results of the antioxidant activity reported in the literature are difficult to compare, since it is strongly influenced by the determination method. Several methods have been described for assessing the antioxidant activity of chemicals present in essential oils and plant extracts. Some authors propose tests that rely on reducing free radicals generated in vitro, resulting from the antioxidant activity of substances assessed, especially the DPPH method, because it is a quick and feasible alternative (Molyneux, 2004).

The products derived from plants serve as a prototype in the control of growth of pathogenic microorganisms and production of less toxic and more effective medicines (Ahmad and Beg, 2001; Kelmanson et al., 2000). There is a growing concern on the part of industries to use less aggressive compounds and the non-inclusion of synthetic raw materials for the preservation of products (Packer and Luz, 2007). As a result, studies have been conducted on essential oils for the discovery of new compounds with antimicrobial and antioxidant potential, since these two mechanisms increase significantly the use of the products (Guleria and Kumar, 2006; Quariachi et al., 2011).

The present study is the first report in the literature addressing the chemical composition and antimicrobial and antioxidant potential of the essential oil of G. kunthiana, and it can serve as the basis for conducting further studies on plants that exhibit unknown biological potential. This way, it is worth noting the importance of phytochemical studies, since they may reveal the presence of active compounds that can explain the biological potentials found.

The essential oil of G. kunthiana has the potential to be used in the food, cosmetics, and pharmaceutical industries, since it exhibits antimicrobial and antioxidant properties.

Table 3. Index of DPPH (2,2-diphenyl-1-picrylhydrazyl) (scavenging \%) and $\mathrm{IC}_{50}$ of the different concentrations of essential oil of Guarea kunthiana tested.

\begin{tabular}{ccc}
\hline Test solutions & DPPH scavenging capacity (\%) & IC $_{\mathbf{5 0}} \boldsymbol{\mu g}_{\mathbf{g} \cdot \mathbf{m L}^{\mathbf{- 1}}}$ \\
\hline BHT & $95.85 \pm 0.04^{\mathrm{a}}$ & $9.27 \pm 0.08^{\mathrm{a}}$ \\
G. kunthiana oil & $91.52 \pm 0.09^{\mathrm{b}}$ & $17.54 \pm 0.18^{\mathrm{b}}$ \\
\hline
\end{tabular}

$\mathrm{BHT}=$ commercial synthetic antioxidant; $\mathrm{DPPH}=2$,2-diphenyl-1-picrylhydrazyl; $\mathrm{IC}_{50}=$ half maximal inhibitory concentration; the values correspond to the mean and standard deviation of triplicates; values followed by the same letter in the column do not differ between them according to T test $(p<0.05)$. 
It is important to stress the importance of further studies, mainly for determining the mechanism of action of this essential oil, as well as the action of its compounds tested in isolation and synergy.

\section{Conclusion}

The GC-MS analysis of the essential oil of G. kunthiana revealed the presence of 13 compounds, among which $\alpha$-zingiberene, $\beta$-sesquiphellandrene, and $\alpha$-curcumene were the major components. With respect to testing the antimicrobial activity, the essential oil was effective against all the microorganisms tested, except for E. coli and $K$. pneumoniae. From a general point of view, Gram-positive bacteria were more susceptible to the action of the essential oil than Gram-negative bacteria. Regarding the antioxidant activity, the oil was effective exhibiting values close to those of the synthetic antioxidant.

\section{Acknowledgements}

The authors are thankful to CAPES (government agency linked to the Brazilian Ministry of Education in charge of promoting high standards for post-graduate courses in Brazil), Araucária Foundation, and CNPq (National Council for Scientific and Technological Development) for their financial support.

\section{References}

ADAMS, R.P., 2007. Identification of essential oil components by gas chromatography/mass spectrometry. London: Allured Pub. Corp, 804 p.

AHMAD, I. and BEG, A.Z., 2001. Antimicrobial and phytochemical studies on 45 Indian medicinal plants against multi-drug resistant human pathogens. Journal of Ethnopharmacology, vol. 74, no. 2, pp. 113-123. PMid:11167029. http://dx.doi.org/10.1016/S03788741(00)00335-4.

ANDRADE, M.A., CARDOSO, M.G., BATISTA, L.R., MALLET, A.C.T. and MACHADO, S.M.F., 2012. Óleos essenciais de Cymbopogonnardus, Cinnamomum zeylanicum e Zingiberofficinale: composição, atividades antioxidante e antibacteriana. Ciência Agronômica, vol. 43, no. 2, pp. 399-408. http://dx.doi.org/10.1590/ S1806-66902012000200025.

AROMDEE, C. and SRIUBOLMAS, N., 2006. Essential oil of the flowers of Azardirachtaindica A. Juss (Meliaceae). Environmental Science and Technology, vol. 28, pp. 115-119.

BAMONIRI, A., EBRAHIMABADI, A.H., MAZOOCHI, A., BEHPOUR, M., KASHI, F.J. and BATOOLI, H., 2010. Antioxidant and antimicrobial activity evaluation and essential oil analysis of Semenovia tragioides Boiss. from Iran. Food Chemistry, vol. 122, no. 3, pp. 553-558. http://dx.doi.org/10.1016/j.foodchem.2010.03.009.

BURT, S., 2004. Essential oils: their antibacterial properties and potential applications in foods-a review. International Journal of Food Microbiology, vol. 94, no. 3, pp. 223-253. PMid:15246235. http://dx.doi.org/10.1016/j.ijfoodmicro.2004.03.022.

CEYHAN, N., KESKIN, D. and UGUR, A., 2012. Antimicrobial activities of different extracts of eight plant spices from four different families against some pathogenic microorganisms. Journal of Food Agriculture and Environment, vol. 10, pp. 193-197.

CHAMPAGNE, D.E., KOUL, O., ISMAN, M.B., SCUDDER, G.G.E. and NEIL TOWERS, G.H., 1992. Biological activity of limonoids from the rutales. Phytochemistry, vol. 31, no. 2, pp. 377-394. http://dx.doi.org/10.1016/0031-9422(92)90003-9.

CLINICAL LABORATORY STANDARDS INSTITUTE - CLSI, 2007. Performance standards for antimicrobial susceptibility testing. Seventh Informational, vol. 35, no. 3, suppl., p. M100S25.

COELHO, A.A.M., 2006. Análise inseticida de extratos de plantas do bioma cerrado sobre triatomíneos e larvas de Aedes aegypti. Brasília: Universidade de Brasília, 104 p. Dissertação de Mestrado em Ciências da Saúde.

CORTEZ, D.A., FERNANDES, J.B., VIEIRA, P.C., SILVA, M.F.G.F. and FERREIRA, A.G., 2000. A limonoid from Thichilia estipulata. Phytochemistry, vol. 55, no. 7, pp. 711-713. PMid:11190385. http://dx.doi.org/10.1016/S0031-9422(00)00298-3.

COSTA, E.V., PINHEIRO, M.L., BARISON, A., CAMPOS, F.R., SALVADOR, M.J., MAIA, B.H., CABRAL, E.C. and EBERLIN, M.N., 2010. Alkaloids from the bark of Guatteriahispida and their evaluation as antioxidant and antimicrobial agents. Journal of Natural Products, vol. 73, no. 6, pp. 1180-1183. PMid:20476748. http://dx.doi.org/10.1021/np100013r.

CROTEAU, R., KUTCHAN, T.M. and LEWIS, N.G., 2000. Natural Products (Secondary Metabolites) In: B BUCHANAN, W GRUISSEM and R JONES, eds. Biochemistry and Molecular Biology of Plants. Rockville: Courrier Companies Inc, pp. 318-1250.

DUDAREVA, N., PICHERSKY, E. and GERSHENZON, J., 2004. Biochemistry of Plant Volatiles. Plant Physiology, vol. 135, no. 4, pp. 1893-1902. PMid:15326281. http://dx.doi.org/10.1104/ pp.104.049981.

FERREIRA, D.F., 2011. Sisvar: a computer statistical analysis system. Ciência e Agrotecnologia, vol. 35, no. 6, pp. 1039-1042. http://dx.doi.org/10.1590/S1413-70542011000600001.

FIGUEIREDO, A.C., BARROSO, J.G., PEDRO, L.G. and SCHEFFER, J.C., 2008. Factors affecting secondary metabolite production in plants: volatile components and essential oils. Flavour and Fragrance Journal, vol. 23, no. 4, pp. 213-226. http://dx.doi.org/10.1002/ffj.1875.

GALINDO, L.A., PULTRINI, A.M. and COSTA, M., 2010. Biological effects of Ocimumgratissimum L. are due to synergic action among multiple compounds present in essential oil. Journal of Natural Medicines, vol. 64, no. 4, pp. 436-441. PMid:20559750. http://dx.doi.org/10.1007/s11418-010-0429-2.

GAO, C.Y., LU, Y.H., TIAN, C.R., XU, J.G., GUO, X.P., ZHOU, R. and HAO, G., 2011. Main nutrients, phenolics, antioxidant activity, DNA damage protective effect and microstructure of Sphallerocarpus gracilis root at different harvest time. Food Chemistry, vol. 127, no. 2, pp. 615-622. PMid:23140708.

GARCEZ, F.R., GARCEZ, W.S., SILVA, A.F.G., BAZZO, R.C. and RESENDE, U.M., 2004. Terpenoid constituents from leaves of Guarea kunthiana. Journal of the Brazilian Chemical Society, vol. 15, no. 5, pp. 767-772. http://dx.doi.org/10.1590/ S0103-50532004000500025.

GILES, M., ZHAO, J., AN, M. and AGBOOLA, S., 2010. Chemical composition and antibacterial propreties of essential oil of three Australian Eucalyptus species. Food Chemistry, vol. 119, no. 2, pp. 731-737. http://dx.doi.org/10.1016/j.foodchem.2009.07.021. 
GOBBO-NETO, L. and LOPES, N.P., 2007. Plantas medicinais: fatores de influência no conteúdo de metabólitos secundários. Quimica Nova, vol. 30, no. 2, pp. 374-381. http://dx.doi.org/10.1590/ S0100-40422007000200026.

GULERIA, S. and KUMAR, A., 2006. Antifungal activity of some Himalayan medicinal plants using direct bioautography. Cellular and Molecular Biology, vol. 5, pp. 95-98.

HOLLEY, R.A. and PATEL, D., 2005. Improvement in shelf-life and safety of perishable foods by plant essential oils and smoke antimicrobials. Food Microbiology, vol. 22, no. 4, pp. 273-292. http://dx.doi.org/10.1016/j.fm.2004.08.006.

JAYAPRAKASHA, G.K. and PATIL, B.S., 2007. In vitro evaluation of the antioxidant activities in fruit extracts from citron and blood orange. Food Chemistry, vol. 101, no. 1, pp. 410-418. http:// dx.doi.org/10.1016/j.foodchem.2005.12.038.

KAILEH, M., BERGHE, W.V., BOONE, E., ESSAWI, T. and HAEGEMAN, G., 2007. Screening of indigenous Palestinian medicinal plants for potential anti-inflammatory and cytotoxic activity. Journal of Ethnopharmacology, vol. 113, no. 3, pp. 510516. PMid:17716845. http://dx.doi.org/10.1016/j.jep.2007.07.008.

KAUR, C. and KAPOOR, H.C., 2001. Antioxidants in fruits and vegetables: the millennium's health. International Food Science and Technology, vol. 36, no. 7, pp. 703-725. http://dx.doi. org/10.1046/j.1365-2621.2001.00513.x.

KAUR, K., JAIN, M., KAUR, T. and JAIN, R., 2009. Antimalarials from nature. Bioorganic and Medicinal Chemistry, vol. 17, no. 9, pp. 3229-3256. PMid:19299148. http://dx.doi.org/10.1016/j. bmc.2009.02.050.

KELMANSON, J.E., JAGER, A.K. and VAN STADEN, J., 2000. Zulu medicinal plants with antibacterial activity. Journal of Ethnopharmacology, vol. 69, no. 3, pp. 241-246. PMid:10722206. http://dx.doi.org/10.1016/S0378-8741(99)00147-6.

KRIFA, M., GHARAD, T. and HAOUALA, R., 2011. Biological activities of essential oil, aqueous and organic extracts of Pituranthos tortuosus (Coss.) Maire. Scientia Horticulturae, vol. 128, no. 1, pp. 61-67. http://dx.doi.org/10.1016/j.scienta.2010.12.016.

LAGO, J.H.G., BROCHINI, C.B. and ROQUE, N.F., 2000. Terpenes from leaves of Guarea macrophylla (Meliaceae). Phytochemistry, vol. 55, no. 7, pp. 727-731. PMid:11190388. http://dx.doi.org/10.1016/S0031-9422(00)00302-2.

LAGO, J.H.G., BROCHINI, C.B. and ROQUE, N.F., 2002. Terpenoids from Guareaguidonia. Phytochemistry, vol. 60, no. 4, pp. 333-338. PMid:12031421. http://dx.doi.org/10.1016/ S0031-9422(02)00089-4.

LAGO, J.H.G., SOARES, M.G., BATISTA-PEREIRA, L.G., SILVA, M.F.G.F., CORRÊA, A.G., FERNANDES, J.B., VIEIRA, P.C. and ROQUE, N.F., 2006. Volatile oil from Guareamacrophylla ssp. tuberculata: seasonal variation and electroantennographic detection by Hypsipyla grandella. Phytochemistry, vol. 67, no. 6, pp. 589-594. PMid:16434069. http://dx.doi.org/10.1016/j. phytochem.2005.12.018.

LIMA, R.C., 2006. Limonóide de Guareakunthiana com potencial leishmanicida. Brasília: Universidade de Brasília, 77 p. Dissertação de Mestrado em Ciências da Saúde.

LORENZI, H. and MATOS, F.J.A., 2008. Plantas medicinais no Brasil: nativas e exóticas. Nova Odessa: Instituto Plantarum de Estudos da Flora Ltda, 576 p.
LORENZI, H., 2009. Árvores brasileiras: manual de identificação e cultivo de plantas arbóreas nativas do Brasil. Nova Odessa: Instituto Plantarum de Estudos da Flora Ltda, 384 p.

LOSSO, J.N., SHAHIDI, F. and BAGCHI, D., 2007. Antiangiogenic functional and medicinal foods. Boca Raton: Taylor and Francis, $736 \mathrm{p}$.

LUO, X., MA, Y., WU, S. and WU, D., 1999. Two novel azadirachtin derivatives from Azadirachtaindica. Journal of Natural Products, vol. 62, no. 7, pp. 1022-1024. PMid:10425132. http://dx.doi. org/10.1021/np980452d.

MESQUITA, M.L., DESRIVOT, J., BORIES, C., FOURNET, A., PAULA, J.E., GRELLIER, P. and ESPINDOLA, L.S., 2005. Antileishmanial and trypanocidal activity of Brazilian cerrado plants. Memórias do Instituto Oswaldo Cruz, vol. 100, no. 7, pp. 783-787. PMid:16419337. http://dx.doi.org/10.1590/S007402762005000700019 .

MOLYNEUX, P., 2004. The use the stable radical diphenylpicrylhydrazyl (DPPH) for estimating antioxidant activity. Songklanakarin. Science and Technology, vol. 26, pp. 211-219.

MOOTOO, B.S., JÁTIVA, C., TINTO, W.F., REYNOLDS, W.F. and MCLEAN, S., 1992. Ecuadorin, a novel tetranortriterpenoid of Guarea kunthiana: structure elucidation by 2-D NMR spectroscopy. Canadian Journal of Chemistry, vol. 70, no. 5, pp. 1260-1264. http://dx.doi.org/10.1139/v92-162.

MORAIS, S.M., CATUNDA JÚNIOR, F.E.A., SILVA, A.R.A., MARTINS NETO, J.S., RONDINA, D. and CARDOSO, J.H.L., 2006. Atividade antioxidante de óleos essenciais de espécies de Croton do nordeste do Brasil. Quimica Nova, vol. 29, no. 5, pp. 907-910. http://dx.doi.org/10.1590/S0100-40422006000500004.

OSEI-SAFO, D., ADDAE-MENSAH, I., GARNEAU, F.X. and KOUMAGLO, H.K., 2010. A comparative study of the antimicrobial activity of the leaf essential oils of chemo-varieties of Clausenaanisata (Willd.) Hook. F. ex Benth. Industrial Crops and Products, vol. 32, no. 3, pp. 634-638. http://dx.doi.org/10.1016/j. indcrop.2010.07.016.

PACCIARONI, A.V., MONGELLI, E., ARIZA, E.L., ROMANO, A., CICCIA, G. and SILVA, G.L., 2000. Bioactive constituents of Conyza albida. Planta Medica, vol. 66, no. 8, pp. 720-723. PMid:11199128. http://dx.doi.org/10.1055/s-2000-9600.

PACKER, J.F. and LUZ, M.M.S., 2007. Método para avaliação e pesquisa da atividade antimicrobiana de produtos de origem natural. Revista Brasileira de Farmacognosia, vol. 17, no. 1, pp. 102-107. http://dx.doi.org/10.1590/S0102-695X2007000100019.

PARTHASARATHY, H. and THOMBARE, S., 2013. Evaluation of antimicrobial activity of Azadirachtaindica, Syzygium aromaticum and Cinnamomum zeyalnicum against oral microflora. Asian Journal of Experimental Biological Sciences, vol. 27, pp. 13-16.

QUARIACHI, E.M., TOMI, P., BOYANZER, A., HAMMOUT, B., DESJOBERT, J.B., COSTA, J. and PAOLINI, J., 2011. Chemical composition and antioxidant activity of essential oils and solvent extracts of Ptychotisverticillata from Marocco. Food and Chemical Toxicology, vol. 49, no. 2, pp. 533-536. PMid:21093522. http:// dx.doi.org/10.1016/j.fct.2010.11.019.

RICE-EVANS, C.A., MILLER, N.J. and PAGANGA, G., 1997. Antioxidant properties of phenolic compounds. Trends in Plant Science, vol. 97, no. 4, pp. 152-159. http://dx.doi.org/10.1016/ S1360-1385(97)01018-2.

RUFINO, M.S.M., ALVES, R.E., BRITO, E.S., MORAIS, S.M., SAMPAIO, C.G., PÉREZ-JIMÉNEZ, J. and SAURA-CALIXTO, 
F.D., 2007. Metodologia Científica: determinação da atividade antioxidante total em frutas pela captura do radical livre DPPH. Comunicado Técnico, vol. 127, pp. 1-4.

SAIRAM, M., ILAVAZHAGAN, G., SHARMA, S.K., DHANRAJ, S.A., SURESH, B., PARIDA, M.M., JANA, A.M., DEVENDRA, K. and SELVAMURTHY, W., 2000. Anti-microbial activity of a new vaginal contraceptive NIM-76 from neem oil (Azadirachtaindica). Journal of Ethnopharmacology, vol. 71, no. 3, pp. 377-382. PMid:10940573. http://dx.doi.org/10.1016/ S0378-8741(99)00211-1.

SANTURIO, J.M., SANTURIO, D.F., POZZATTI, P., MORAES, C., FRANCHIN, P.R. and ALVES, S.H., 2007. Atividade antimicrobiana dos óleos essenciais de orégano, tomilho e canela frente a sorovares de Salmonella de origem avícola. Ciência Rural, vol. 37, no. 3, pp. 803-808. http://dx.doi.org/10.1590/ S0103-84782007000300031.

SARTORATTO, A., MACHADO, A.L.M., DELARMELINA, C., FIGUEIRA, G.M., DUARTE, M.C.T. and REHDER, V.L.G., 2004. Composition and antimicrobial activity of essential oils from aromatic plants used in Brazil. Brazilian Journal of Microbiology, vol. 35, no. 4, pp. 275-280. http://dx.doi.org/10.1590/S151783822004000300001 .

SCHERER, R. and GODOY, H.T., 2009. Antioxidant activity index (AAI) by 2,2-diphenyl-1-picrylhydrazyl method. Food Chemistry, vol. 112, no. 3, pp. 654-658. http://dx.doi.org/10.1016/j. foodchem.2008.06.026.

SCUR, M.C., PINTO, F.G.S., PANDINI, J.A., COSTA, W.F., LEITE, C.W. and TEMPONI, L.G., 2016. Antimicrobial and antioxidant activity of essencial oil and different plant extracts of Psidium cattleianum Sabine. Brazilian Journal of Biology = Revista Brasileira de Biologia, vol. 72, no. 1, pp. 101-108. http:// dx.doi.org/10.1590/1519-6984.13714.

SHAHIDI, F., JANITHA, P.K. and WANASUNDARA, P.D., 1992. Phenolic antioxidants. Critical Reviews in Food Science and Nutrition, vol. 32, no. 1, pp. 67-103. PMid:1290586. http:// dx.doi.org/10.1080/10408399209527581.

SIANI, A.C., SAMPAIO, A.L.F., SOUZA, M.C., HENRIQUES, M.G.M.O., RAMOS, M.F.S., 2000. Óleos essenciais: potencial antiinflamatório. Biotecnologia Ciencia and Desenvolvimento, vol. 16 , pp. $38-43$.
SILVA, J., ABEBE, W., SOUZA, S.M., DUARTE, V.G., MACHADO, M.I.L. and MATOS, F.J.A., 2003. Analgesic and anti-inflamatory effects of essential oil of Eucalyptus. Journal of Ethnopharmacology, vol. 89, no. 2-3, pp. 277-283. PMid:14611892. http://dx.doi.org/10.1016/j.jep.2003.09.007.

SOARES, L.R., SILVA, A.C.Q., FREIRE, T.V., GARCEZ, F.R. and GARCEZ, W.S., 2012. Sesquiterpenos de sementes de Guareaguidonia (Meliaceae). Quimica Nova, vol. 35, no. 2, pp. 323-326. http://dx.doi.org/10.1590/S0100-40422012000200017.

SOUSA, A.C., ALVIANO, D.S., BLANK, A.F., ALVES, P.B., ALVIANO, C.S. and GATTASS, C.R., 2004. Melissa officinalis L. essential oil: antitumoral and antioxidant activities. The Journal of Pharmacy and Pharmacology, vol. 56, no. 5, pp. 677-681. PMid:15142347. http://dx.doi.org/10.1211/0022357023321.

TROMBETTA, D., CASTELLI, F., SARPIETRO, M.G., VENUTI, V., CRISTANI, M., DANIELE, C., SAIJA, A., MAZZANTI, G. and BISIGNANO, G., 2005. Mechanisms of Antibacterial action of three monoterpenes. Antimicrobial Agents and Chemotherapy, vol. 49, no. 6, pp. 2474-2478. PMid:15917549. http://dx.doi. org/10.1128/AAC.49.6.2474-2478.2005.

VAGIONAS, K., GRAIKOU, K., NGASSAPA, O., RUNVORO, D. and CHINOU, I., 2007. Composition and antimicrobial activity of the essential oils of three Satureja species growing in Tanzania. Food Chemistry, vol. 103, no. 2, pp. 319-324. http:// dx.doi.org/10.1016/j.foodchem.2006.07.051.

VEIGA-JÚNIOR, V.F. and PINTO, A.C., 2002. O gênero Copaifera L. Quimica Nova, vol. 25, no. 2, pp. 273-286. http:// dx.doi.org/10.1590/S0100-40422002000200016.

WEBER, L.D., PINTO, F.G.S., SCUR, M.C., SOUZA, J.G.L., COSTA, W.F. and LEITE, C.W., 2014. Chemical composition and antimicrobial and antioxidant activity of essential oil and various plant extracts from Prunus myrtifolia. African Journal of Agricultural Research, vol. 9, no. 9, pp. 846-853. http://dx.doi. org/10.5897/AJAR2013.8260.

YESIL CELIKTAS, O., KOCABAS, E.E.H., BEDIR, E., SUKAN, F.V., OZEK, T. and BASER, K.H.C., 2007. Antimicrobial activities of methanol extracts and essential oils of Rosmarinusofficinalis, depending on location and seasonal variations. Food Chemistry, vol. 100 , no. 2, pp. 553-559. http://dx.doi.org/10.1016/j. foodchem.2005.10.011. 